\title{
Polyethylene terephthalate nanoparticles effect on RAW 264.7 macrophage cells
}

\author{
J. Cristóbal Aguilar-Guzmán¹, Katarzyna Bejtka², Marco Fontana², Eugenia Valsami-Jones³, \\ Anaid Meza Villezcas ${ }^{1}$, Rafael Vazquez-Duhalt ${ }^{1}$ and Ana G. Rodríguez-Hernández ${ }^{1,4^{*}}$
}

\begin{abstract}
Plastic pollution is a major environmental concern due to its pervasiveness which continues to increase year on year, as a result of a continuing acceleration in global plastic production and use. Polyethylene terephthalate (PET) is among the most produced plastics, commonly used as food and beverage containers. Once released in the environment, the degradation of plastic materials produces micro-and nano-plastics, with a particular concern about potential toxicological effects if they cross epithelial barriers via inhalation or ingestion. In this work, the effect of PET nanoparticles (PET-NPs) ( $\leq 250 \mathrm{~d}$.nm) was assayed on mouse macrophages cell line (RAW 264.7) in in vitro experiments. Results showed that PET nanoparticles were easily internalized by the cells, $15 \mu \mathrm{g} / \mathrm{mL}$ of nanoparticles concentration had exhibited effects in cell proliferation and a slightly increased production of Reactive Oxygen Species (ROS), which seems to trigger cell response as foreign particles related to upregulation of PCDH12, IGH-V10, ROBO1 genes, and cell maintenance functions, related to FTSJ2 gene upregulation. Thus, the RAW 264.7 results showed here are useful towards for a preliminary and understanding of the potentially toxic effects related to PET nanoparticles and complementary to other in vitro assays, as the first step into the development of the risk assessment framework.
\end{abstract}

Keywords: Nanoplastics, Microplastics, Plastic pollution, Macrophages, Cell internalization

\section{Introduction}

Unequivocally plastics are among the most used materials worldwide due to their versatility, low production cost, easy manufacturing, chemical stability, etc [1]. Plastic global production in 2018 was around 359 million tons (Plastics Europe Market Research Group and Conversion Market \& Strategy $\mathrm{GmbH})$. Among plastics, polyethylene terephthalate (PET) production was estimated in 2020 to be approximately 23.7 million metric tons [2]. PET has been widely used for decades for food packing and beverages because of its high resistance, microorganism repulsion and corrosion resistance (FDA). Unfortunately, this enormous manufacturing entails a big waste production, making plastics one of the most critical pollutants of

\footnotetext{
*Correspondence: agrodriguez@ens.cnyn.unam.mx

${ }^{1}$ Center for Nanosciences and Nanotechnology, Universidad Nacional

Autónoma de México, Ensenada, B.C, México

Full list of author information is available at the end of the article
}

modern times. According to the World Economic Forum, the estimation for 2020 of plastic waste floating in the sea worldwide is more than 250,000 tonnes.

The environmental degradation of plastic pollutants (i.e. by UV light and mechanical forces) is one of the sources of microplastics (MPs $<5 \mathrm{~mm}$ ) and nanoplastics $(\mathrm{NPs}<100 \mathrm{~nm})$, with presence in aquatic systems [3-5], and terrestrial environments, even in polar regions [6], showing the plastic ubiquity. Thus, the environmental and health risk associated with micro-and nano-plastics has become a global concern because of the constant organism [4, 7-10] and human exposure. Recently microplastics have been isolated from the human placenta [11] and feces in adults and infants [12]. These findings make evident the unavoidable and involuntary microplastics uptake by different routes (ingestion or inhalation [13]). In general, oral ingestion route has caught more attention due to the presence of MPs and NPs in foodstuffs such as table salt $[14,15]$, different beverages $[16,17]$, and meat 
used for human consumption [18-20]. In addition, some studies have calculated the microplastic average human ingestion. Nor and colleagues have estimated that microplastic median individual intake rates are $184-583 \mathrm{ng} /$ day [21], whilst Senathirajah and colleagues have estimated a higher concentration (14-714 mg/day) [22]. Additionally, the presence of microplastic into different organisms supports the theory about the ability of nanoplastics to cross the anatomical barriers and a potential organ invasion, because it has been probed that nanoplastics can be easily internalized by different cells in in-vitro studies [23-25].

Despite that so far, no studies are available reporting the nanoplastics presence in the environment, due to the difficulty to identify and isolate them, there is a particular concern about plausible nanoplastics toxicity and its effects on different organisms. The current strategy for toxicological evaluations of nanoplastics is focused on using commercial polystyrene (PS) nanoparticles on different biological cell models. Different cell lines have been used as models because they maintain representative functional features, that let to analyze clearly and invariably a well-known cell response. Cell lines such as human epithelial colorectal adenocarcinoma (Caco2) [26], human cervical adenocarcinoma (HeLa) [27], have been used as a model of anatomical barriers. On the other hand, human peripheral blood monocyte cells (PBMCs), human monocyte (UP37 and THP-1), mouse macrophage (DMBM-2) [28], and murine macrophages (RAW 264.7), have been used as immune cells models for in vitro nanotoxicological evaluation of polystyrene beads [25].

Macrophages cell line (RAW 264.7) is representative and versatile cells worldwide accepted as a macrophage model. According to authors such as Bordbar, "while metabolic status can greatly vary depending on macrophage type or stimulated state, the murine leukemic monocyte-macrophage cell line RAW 264.7 has been an amenable in vitro model of both macrophage and monocyte functions as it exhibits key characteristics representative of different macrophage types in vivo" [29].

In general, it is considered that once nanoplastics cross anatomical barriers (intestinal or alveolar), an innate immunological response could begin through macrophages. Macrophages play many roles because they are innate immune specialized cells, where the main function is to elicit an organism's defense against foreign bodies and antigens. As scavengers, they rid of dying cells, pathogens [30] and other debris, and they are first-line cellular responders to inhaled particulate matter in the lungs [31]. In the gut the macrophages reside in the lamina propria and are associated mainly with intestinal crypts [32], contribute to barrier integrity with high phagocytic activity [33], and they are the first line of foreign agents host defense and are the most abundant immune cells in the intestine [33-35]. These cells present a wide functional diversity depending on their anatomical location and more importantly, related to environmental stimuli to which they are exposed, modulating their physiological response.

Recently, RAW 264.7 has already been used as macrophage model for polystyrene (PS) nanoparticles toxicity analysis, where authors observed ROS increment and lipid accumulation [25]. However, commercial PS nanoparticles do not represent the expected nanoplastics in the environment.

PET in micro and nanoscale has been reported as pollutants in the environment [36] and in marine litter [37], nevertheless, there are scarce studies about their toxicity due to the difficult isolation and quantification. Recently, authors such as Magri [23], RodriguezHernandez [24] and Lionetto [38] have developed some reliable strategies for producing polyethylene terephthalate nanoparticles (PET-NPs), an environmentally relevant and representative nanoplastic from plastic pollution. PET-NPs $(224 \pm 46$ d.nm $)$ produced by Rodriguez-Hernandez and colleagues, which maintains the ultrastructure and the chemical composition from their origin and analogous to pristine material [24], has been already used as a model in the identification and characterization of nanoplastics in environment matrices [39]. Moreover, Magri and Rodriguez-Hernandez's studies have shown that PET-NPs can be easily internalized by cells $[23,24]$ in vitro experiments. However, the cell response to nanoplastics, once they are internalized, has not been so far elucidated.

Considering all the above mentioned is important to analyze a more representative nanoplastic model. Then in this work, PET nanoparticles with hydrodynamic diameter up to $250 \mathrm{~nm}$ obtained under controlled conditions, were characterized. Different PET-NPs concentrations $(0.1 \mu \mathrm{g} / \mathrm{mL}, 1 \mu \mathrm{g} / \mathrm{mL}, 10 \mu \mathrm{g} /$ $\mathrm{mL}, 100 \mu \mathrm{g} / \mathrm{mL}, 1 \mathrm{mg} / \mathrm{mL}$ and $10 \mathrm{mg} / \mathrm{mL}$ ) were used for in vitro cytotoxicity assessment, analyzing the effects in viability and cell proliferation, mitochondrial damage and ROS production on macrophage cell line (RAW 264.7), in order to find the toxic relevant exposure concentrations. Additionally, the presence of nanoparticles into cell vesicles was corroborated by confocal and transmission electron microscopy, and the effects of exposure to critical PET-NPs concentration on the gene transcription were also studied and discussed. 

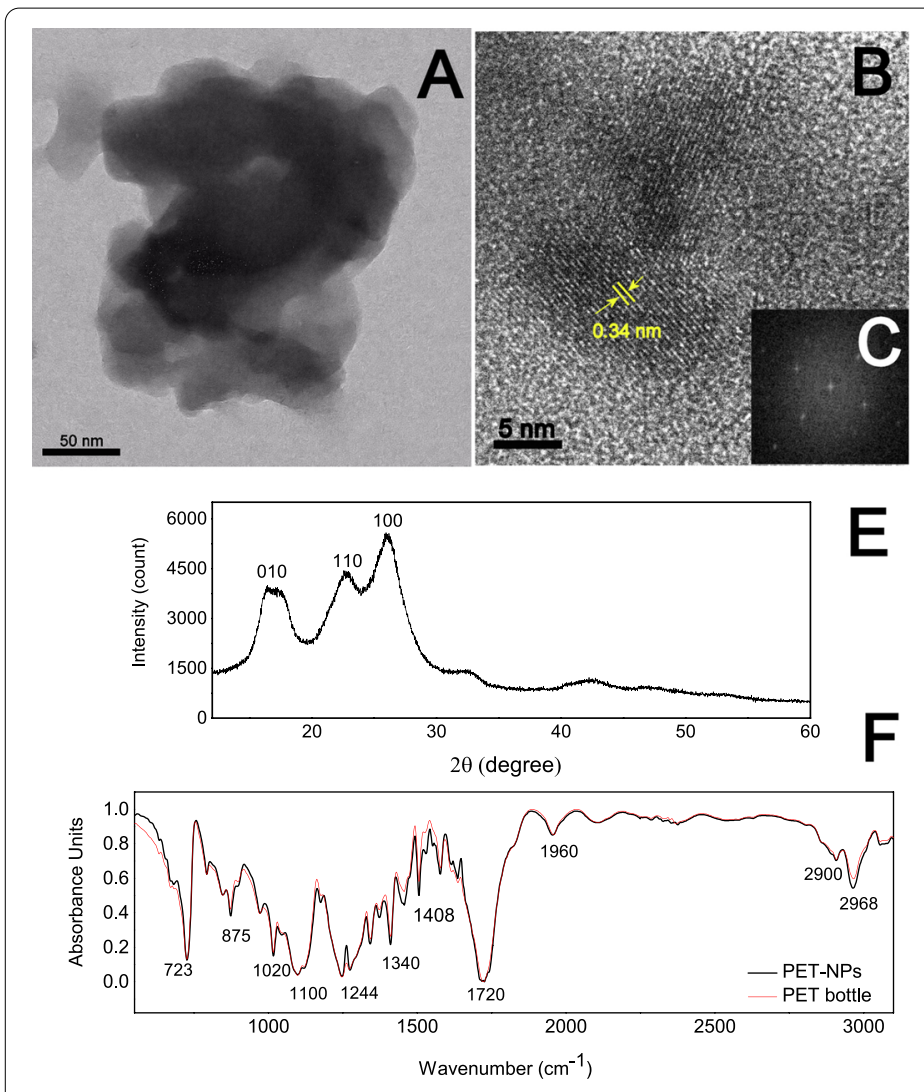

Fig. 1 PET NP-s characterization. TEM images of PET-NPs at different magnifications (A, B). Crystal planes (B) and its FFT (C). PET-NPs size distribution obtained after precipitation by A4F analysis (D). The XRD spectra (E), FTIR spectra (F) and the size distribution of nanoparticles after settling, used for cell experiments $(\mathbf{G})$

\section{Results}

\section{PET-NPs characterization}

The morphological characteristics of PET-NPs were analyzed by Transmission Electron Microscopy (TEM). Bright-field images show PET-NPs with irregular shapes and sizes between $50-250 \mathrm{~nm}$ (Fig. 1A). The polycrystalline structure of PET-NPs was observed in detail by High-Resolution Transmission (HRTEM) image (Fig. 1B), whereas the lattice spacing was measured throughout related Fast Fourier Transform (FFT) image (Fig. 1C), which give an interplanar distance of $0.34 \mathrm{~nm}$. X-ray diffraction (XRD) spectra of PET-NPs showed the peaks identified as (010), (110) and (100) planes (Fig. 1E), related to pristine polyethylene terephthalate structure and the crystallographic table 00-0600989. FTIR spectra from PET-NPs and PET bottle showed no differences between the two materials. The absorption bands observed at $3100-2800 \mathrm{~cm}^{-1}$ were the signal commonly attributed to aromatic and aliphatic $-\mathrm{C}-\mathrm{H}$ bond stretching, $1720 \mathrm{~cm}^{-1}$ to ester carbonyl bond stretching, $1300 \mathrm{~cm}^{-1}$ to ester group
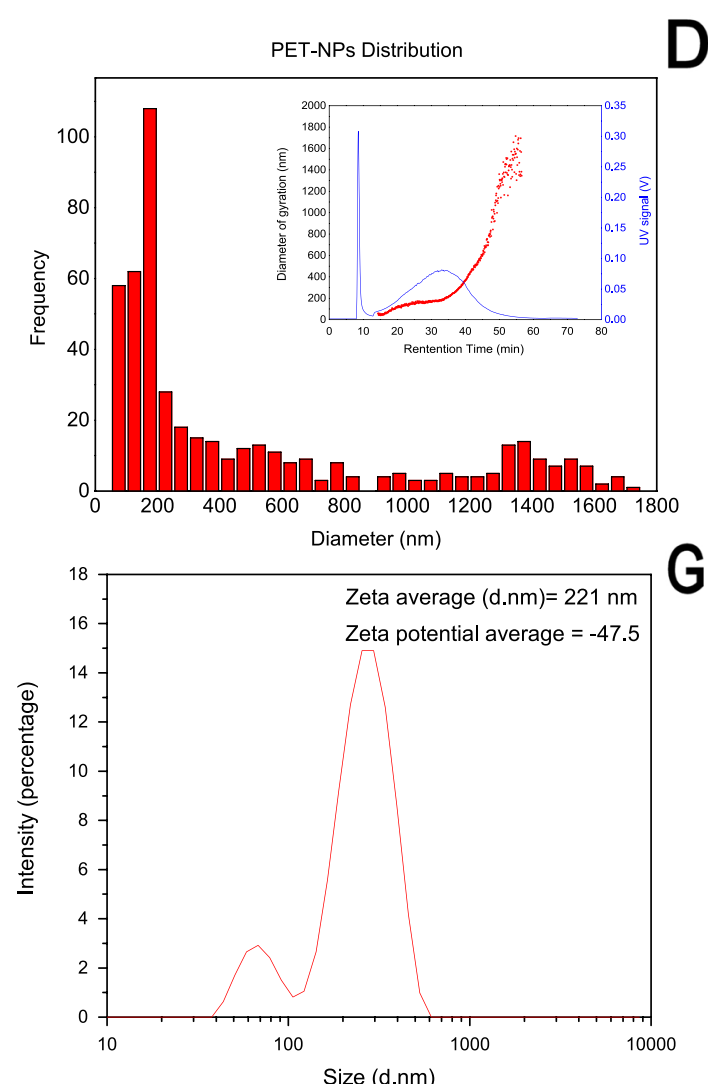

G stretching and $1100 \mathrm{~cm}^{-1}$ to the methylene group from pristine PET [40]. Asymmetrical flow field-flow fractionation (A4F) showed the PET-NPs size distribution obtained after precipitation (Fig. 1D), with the highest amount with a particle diameter of $<200 \mathrm{~nm}$. The upper fraction $(\approx 85 \%)$ after settling into a cylinder $(1$ L) with $0.5 \%$ SDS of original PET-NPs solution, was separated and recovered. DLS results (Fig. 1G) showed the hydrodynamic average distribution $(221 \mathrm{~nm})$ and the zeta potential of selected of PET-NPs $(-47.5 \mathrm{mV})$ in $0.5 \%$ SDS. In addition, hydrodynamic diameter and zeta potential of PET-NPs resuspended in different media showed the interaction of the nanoparticles with them (Table 1). In ultrapure water, the hydrodynamic diameter was the highest (2260 d.nm), whereas the zeta potential $(3.6 \mathrm{mV})$ showed the trend of particle agglomeration. PET-NPs suspended in DMEM showed a diameter of $1197 \mathrm{~d} . \mathrm{nm}$ and zeta potential of $-18 \mathrm{mV}$, suspended in FBS the values were 631 d.nm and $-3.5 \mathrm{mV}$, while suspended in a supplemented DMEM the values were $858 \mathrm{~d} . \mathrm{nm}$ and $-12.3 \mathrm{mV}$, showing a 
different trend to aggregation according the medium composition.

\section{Cell viability assay}

PET-NPs cytotoxicity assayed by resazurin reduction was assessed on macrophages RAW 264.7 cell line after $24 \mathrm{~h}$, $48 \mathrm{~h}$, and $72 \mathrm{~h}$ exposure. According to measurements, the resazurin reduction activity increased as the concentration of PET-NPs increased at $24 \mathrm{~h}$, with the highest reduction at $10 \mu \mathrm{g} / \mathrm{mL}$ and $100 \mu \mathrm{g} / \mathrm{mL}$ PET-NPs. However, no statistical differences among PET-NPs concentration at $48 \mathrm{~h}$ and $72 \mathrm{~h}$ of incubation were found (Fig. 2A). In addition, the resazurin reduction was higher than the control experiments (absence of PET-NPs) at all incubation times tested. The same effect was detected by using a sharper range of PETNPs concentrations (Fig. 2B). Nevertheless, if cell number counts are plotted vs their related fluorescence, the effect of PET-NPs in cell proliferation reduction is clearly observed at 48 and $72 \mathrm{~h}$, where the number of cells is lower than control and even though resazurin reduction is higher for cells incubated in presence of PET-NPs (Fig. 2E).

\section{Microarray analysis}

Microarray analyses were performed on cells with and without the presence of PET-NPs to determine the transcriptional changes in macrophage genes after $48 \mathrm{~h}$ incubation in the presence of $15 \mathrm{~g} / \mathrm{mL}$ PET-NPs. The microarray datasets generated using the customdesigned Mus musculus oligonucleotide array containing 65-mer probe sets representing 22,000 transcripts were analyzed. Only 4 upregulated with a $\log 2$ (w/wo) $\geq 2$, and no downregulated genes were found (Fig. 2D). The upregulated genes were: Immunoglobulin heavy variable 10 (IGH-V10), Roundabout Guidance Receptor 1 (ROBO1), Protocadherin 12 (PCDH12), and importantly RNA methyltransferase homolog 2 (FTSJ2), also named as Mitochondrial rRNA Methyltransferase 2 (MRM2), where IGH-V10 $(\log 2=2.0), \quad$ ROBO1 $\quad(\log 2=2.2)$, PCDH12 $(\log 2=2.5)$, and FTSJ2 $(\log 2=5.2)$.

\section{Detection of reactive oxygen species (ROS)}

ROS production of cell cultures was estimated by using 2,7'-dichlorodihydrofluorescein diacetate (DCFDA) staining, and $50 \mathrm{M}$ tert-butyl hydroperoxide as a positive control. Macrophage cells exposed to PET-NPs showed a slight but significantly increased intracellular ROS production (Fig. 2C) at all concentrations assayed. This slight ROS increase seems not to be correlated to the PET-NPs concentration increment.

\section{Detection of ROS production by confocal microscopy}

Confocal laser scanning microscope images of macrophages in the presence of $15 \mu \mathrm{g} / \mathrm{mL}$ of PET-NPs are shown in Fig. 3. Cells can be easily identified by DAPI nucleus staining (blue signal) and ROS production by DCF (green signal). Fluorescent-labeled PET-NPs with Nile Red (PET-NPs-NR) are detected by the red signal. The green fluorescence signal induced by the ROS production is located around the cell nucleus, and the increment of ROS production from 24 to $72 \mathrm{~h}$ is clearly associated with the presence of PET-NPs, showed by the colocalization of DFC signal and fluorescent-labelled PET-NPs-NR (white arrows Fig. 3).

\section{Mitochondrial observation}

Confocal images of mitochondria from macrophages in presence of $15 \mu \mathrm{g} / \mathrm{mL}$ of PET-NPs are shown in Fig. 4 . Mito-ID signaling, and Merge (DIC and Mito-ID) images showed no significant differences to Mito-ID intensity between cells in presence of PET-NPs and control at 24, 48 and $72 \mathrm{~h}$ of incubation.

\section{Nanoplastics cell internalization}

PET-NPs cell internalization was observed with more detail by TEM images of macrophages exposed to plastic nanoparticles. Incubated cells in the presence of PET-NPs at different times showed electron-dense zones inside vesicles (endosomes) attributed to nanoparticle internalization, as shown in Fig. 5. The PET-NPs have changed the endosomes' structure (white arrows) compared to vesicles of control cells (black arrows); this could indicate an apparent disruption in the endosome's integrity after 24 and $72 \mathrm{~h}$ of incubation. A betterdetailed observation to Fig. 5F of cell vesicles after incubation with PET-NPs (Fig. 6F1), showed the particles inside of approximately $100 \mathrm{~nm}$ of diameter (Fig. 6F2)

\footnotetext{
(See figure on next page.)

Fig. 2 Cell viability, ROS and gene evaluation. Cytotoxic effect of PET-NPs on RAW 264.7 cells after incubation with (A) 0.0001 to 10 mg/mL or (B) $7.5,15,30$, and $60 \mu \mathrm{g} / \mathrm{mL}$ of nanoparticles for 24,48 , and $72 \mathrm{~h}$. DMSO was set up as a positive control for the viability assays ( $n=3$ ). Additionally, PET-NPs by themselves have not shown fluorescence at 24, 48, $72 \mathrm{~h}$ of incubation. C ROS production test of the macrophages exposed to PET-NPs. TBHP was set up as a positive control for the ROS production assays $(n=3)$. All data were expressed as the mean \pm SD. All differences were identified via one-way ANOVA, followed by Tukey's multiple comparison test. * represented the significantly different $(p<0.05, p<0.01, p<0.001$, and $p<0.0001)$ as compared with the control. D Upregulated genes (log2 $>2$ ) from macrophages incubated in presence of PET-NPs. E Plot of cell number vs fluorescence (resazurin reduction). Results showed no significant differences between control and PET-NPs at $24 \mathrm{~h}$. However, an increment in fluorescence is observed at 48 and $72 \mathrm{~h} \mathrm{(15} \mathrm{and} 30 \mu \mathrm{g} / \mathrm{mL}$ of PET-NPs), but the cell amount from the same time showed a decrement in all samples incubated in presence of PET-NPs and compared to control
} 

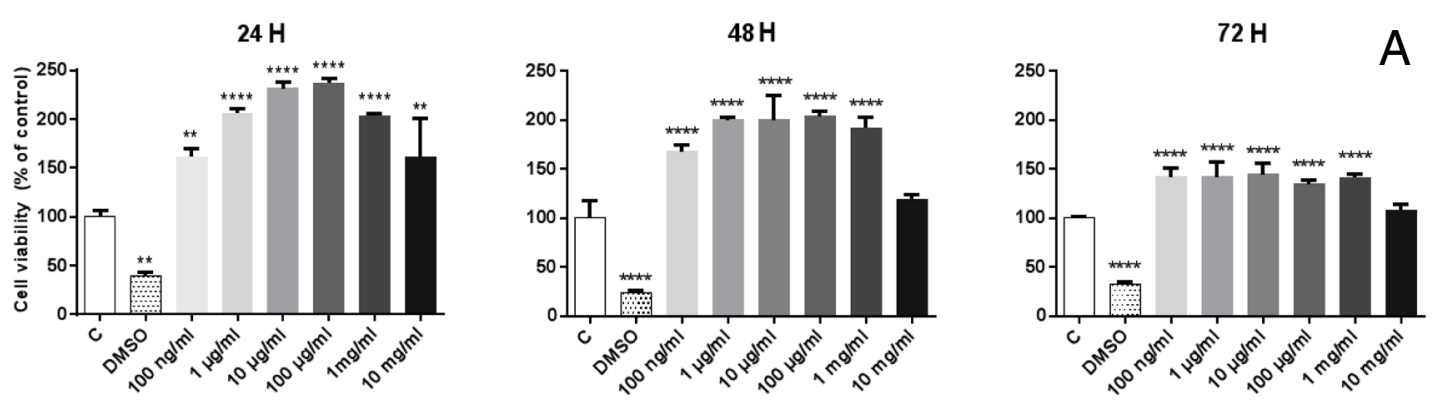

$24 \mathrm{H}$

$48 \mathrm{H}$
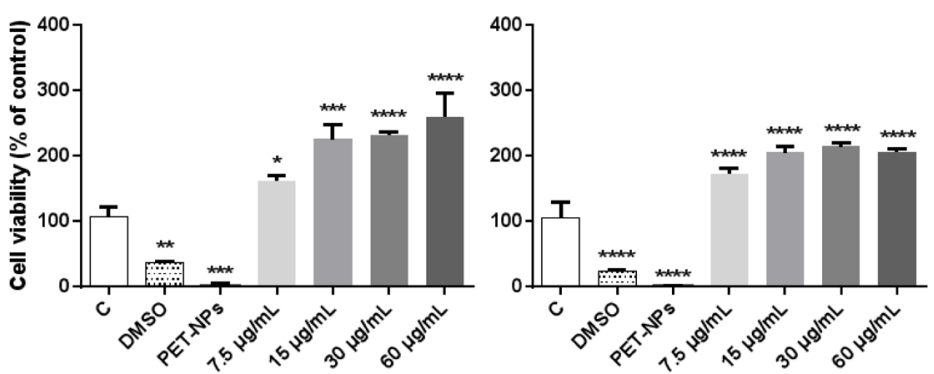

$72 \mathrm{H}$

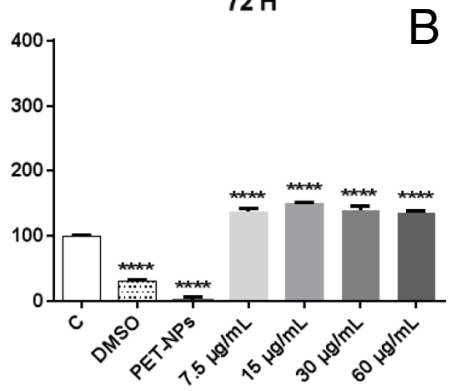

$24 \mathrm{H}$

$48 \mathrm{H}$
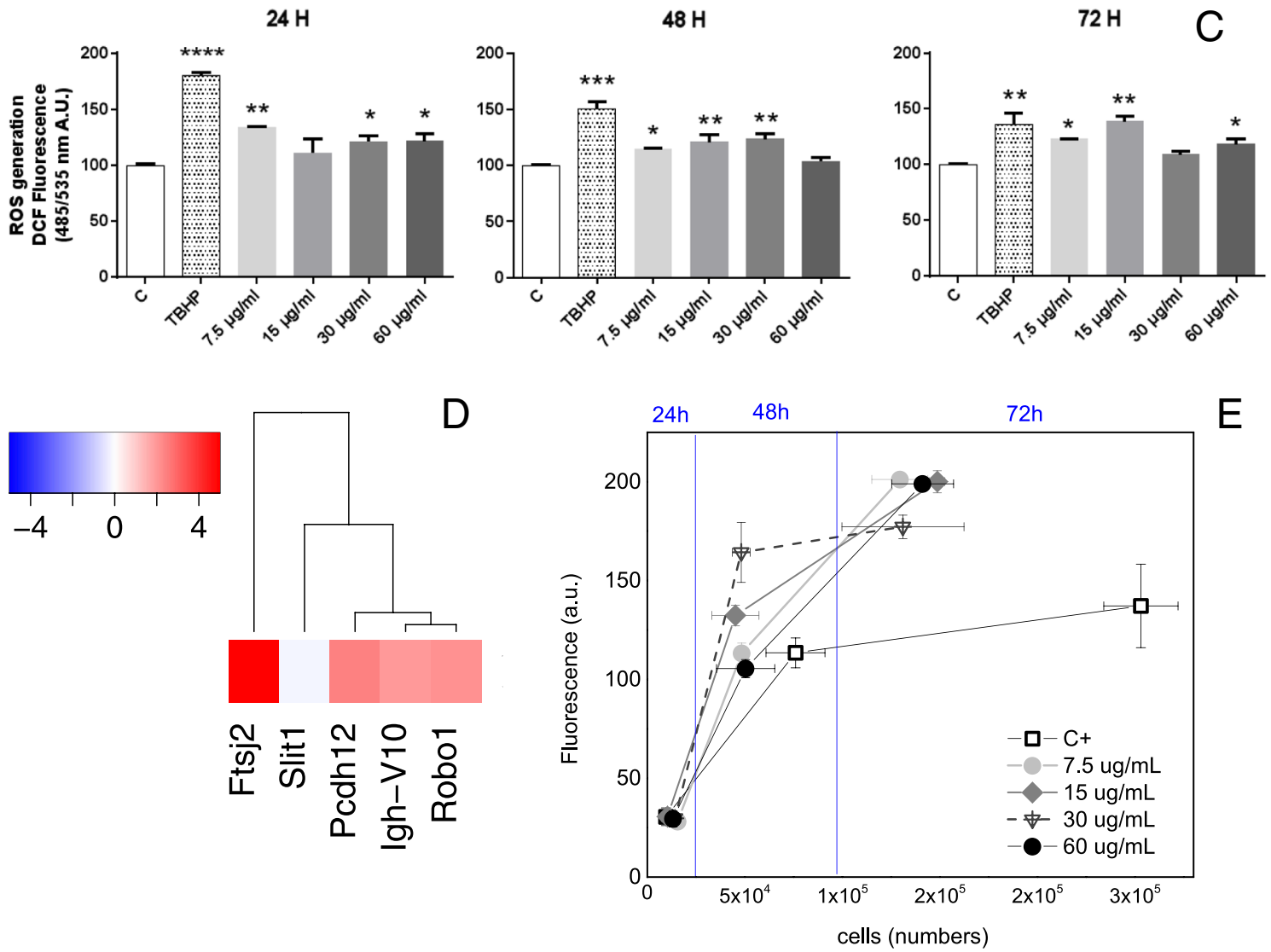

$E$

Fig. 2 (See legend on previous page.) 


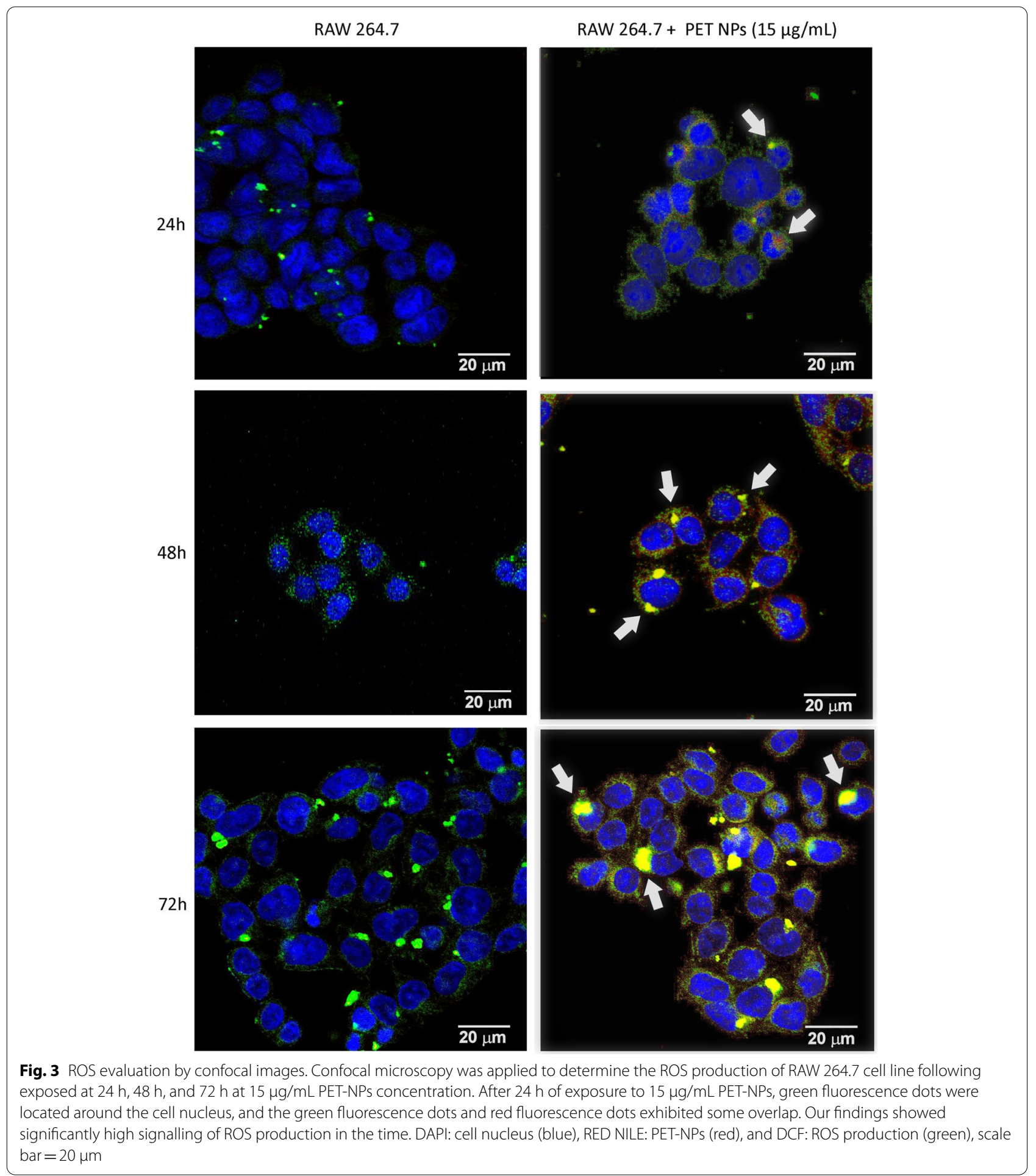

and irregular border (Fig. 6F3). HRTEM images from particles (Fig. 6F4), revealed the crystallographic pattern of materials with interatomic planes distances of $0.34 \mathrm{~nm}$ in agreement with PET material. In addition, images of PET nanoparticles in the vicinity of macrophages showed the ruffles projection of cell membrane with unilateral enveloping movement around a PET-NPs cluster (Fig. 7). 


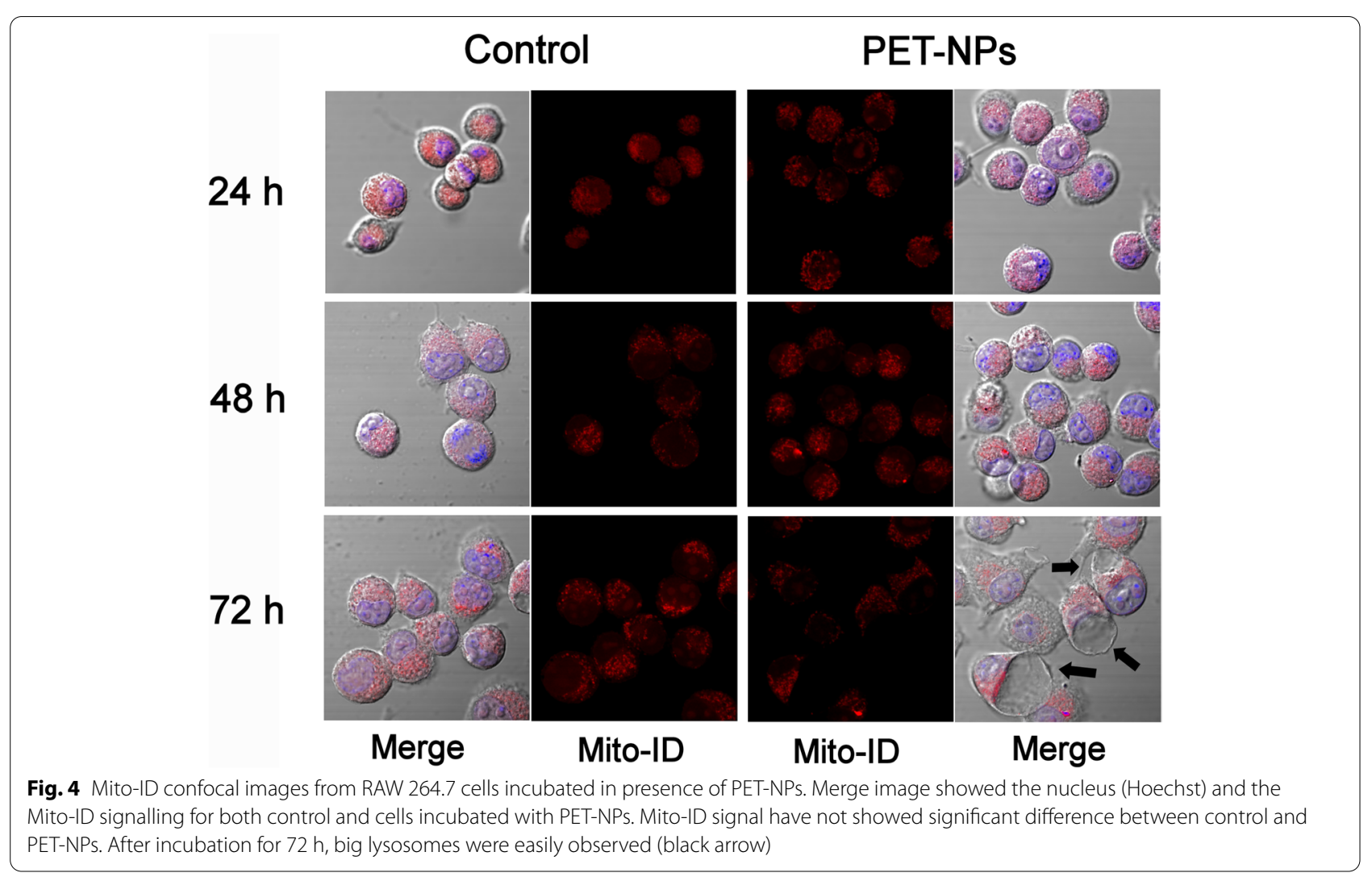

\section{Discussion}

The present study addressed the potential toxicological effects of polyethylene nanoparticles obtained under lab-controlled conditions, in in vitro experiments using macrophage cell line (RAW 264.7). Our results showed that macrophage response to the presence of PET-NPs was an increment of cell viability, determine by resazurin reduction (Fig. $2 \mathrm{~A}$ and $\mathrm{B}$ ) with data up to $240 \%$ vs control at 24 and $48 \mathrm{~h}$ in all concentrations, and the highest reduction was observed between $10-100 \mu \mathrm{g} / \mathrm{mL}$ (Fig. 2A). This fact was corroborated with a sharper cytotoxicity assay $(15,30$ and $60 \mu \mathrm{g} /$ $\mathrm{mL}$ ) (Fig. 2B), where cell viability presented the same resazurin reduction percentage that $10-100 \mu \mathrm{g} / \mathrm{mL}$ range (approximately 240\%). However, the cell number counting showed a different trend, especially at 48 and $72 \mathrm{~h}$, where fewer cells were detected in PET-NPs cell cultures (Fig. 2E). This difference between resazurin reduction and cell proliferation could be associated with impaired cytosolic $\mathrm{NAD}(\mathrm{P}) \mathrm{H}$ mitochondrial oxidation rather than increased viability [41]. Nevertheless, neither microarray results (Fig. 2D) nor MitoID detection (Fig. 4), showed an effect on NAD(P) $\mathrm{H}$ genes (upper or downregulation) or a decrement in mitochondria signaling. Moreover, superoxide radical's detection showed that cells incubated in the presence of PET-NPs cause an increment in the ROS production compared to non-stimulated cells (Fig. 2C), and $15 \mu \mathrm{g} / \mathrm{mL}$ was the concentration that presented a constant and maintained ROS production by macrophages (Fig. 2C). Then, we can asseverate that PET-NPs in the range of $10-100 \mu \mathrm{g} / \mathrm{mL}$, have altered the cell physiology affecting cell viability and proliferation, especially at 24 and $48 \mathrm{~h}$ of incubation. In addition, our findings have demonstrated that the highest effect was observed with PET-NPs concentration at $15 \mu \mathrm{g} / \mathrm{mL}$, because it's the minimal concentration with the highest effect in cell resazurin reduction and maintained ROS production.

Additionally, the resazurin reduction increment after $48 \mathrm{~h}$ of incubation with $15 \mu \mathrm{g} / \mathrm{mL}$ of PET-NPs matches the increase in the expression of FTSJ2 gen $(\log 2=5.2)$, a nucleolar and evolutionary conserved family of RNA methyltransferase [35], the transcript augmentation of which has been associated to inhibition of cell functions such as invasion and migration [42-44]. Usually, FTSJ2 (also identified as MRM2) is known to encode for a mitochondrial rRNA methyltransferase responsible for modification of nucleotides of the 16S rRNA A-loop, an essential component of the peptidyl transferase. The inactivation of MRM2 in human cells by RNA interference 


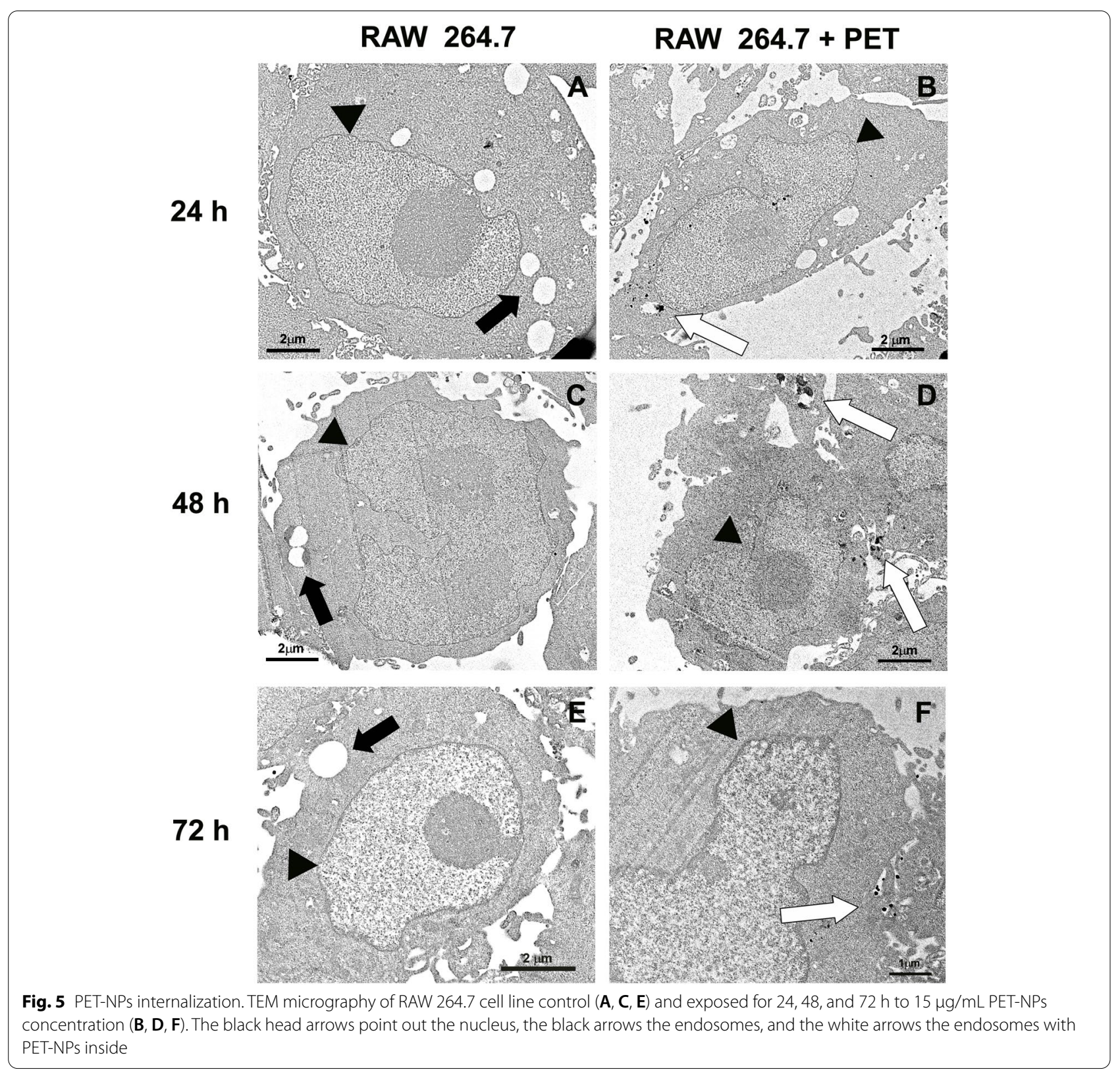

resulted in mitochondrial respiratory incompetence as a consequence of diminished mitochondrial translation [45] and vice versa.Thus, the increase in macrophage FTSJ2 transcription in this work could be evidence of cell maintenance requirements escalation in response to PET NPs presence, however, more experiments should be performed to corroborate it.

On the other hand, the presence of the most overexpressed gene FTSJ2 (also known as MRM2), suggests an additional and unexpected effect to the presence of PET-NPs. The most similar three-dimensional folding to RNA methyltransferase encoded by MRM2 is the catechol-O-methyltransferase [46]. The catechol $\mathrm{O}$-methyltransferase is similar in size to MRM2 protein and superposes with a rmsd of $1.97 \AA$ for $109 \mathrm{C} \alpha$ atoms that could be judged structurally equivalent by LSQMAN [47]. The catechol-O-methyltransferase is known as an enzyme involved in the transformation of physiologically active endogenous or exogenous phenolic compounds, suppressing the chemical reactivity and maintaining these compounds at a safe level [48]. Thus, this enzyme is involved in an important elimination and defense metabolic pathway for endogenous and exogenous compounds such as amines, estrogens, drugs, and 


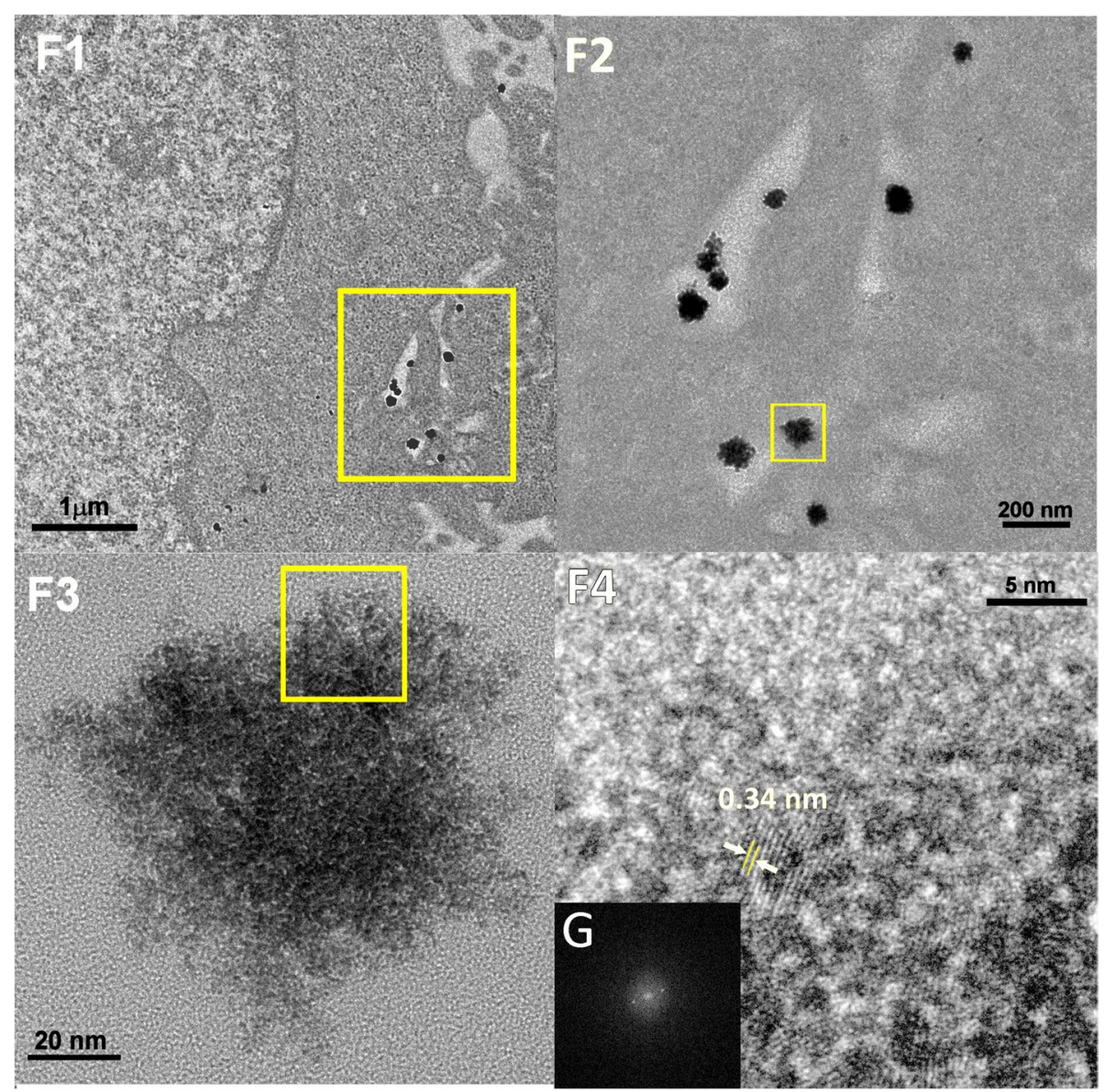

Fig. 6 PET-NPs internalization (magnification). TEM micrograph detailed magnification from Fig. 5-F, of PET-NPs internalized by RAW 264.7 cell line $(\mathbf{F 1}, \mathbf{F 2}, \mathbf{F 3}, \mathbf{F 4})$. Yellow squares indicate the sequence of magnification zone and white arrows point out the planar distance of PET semicrystalline $(\mathbf{F} \mathbf{4})$, and its FTT diffraction pattern (G)
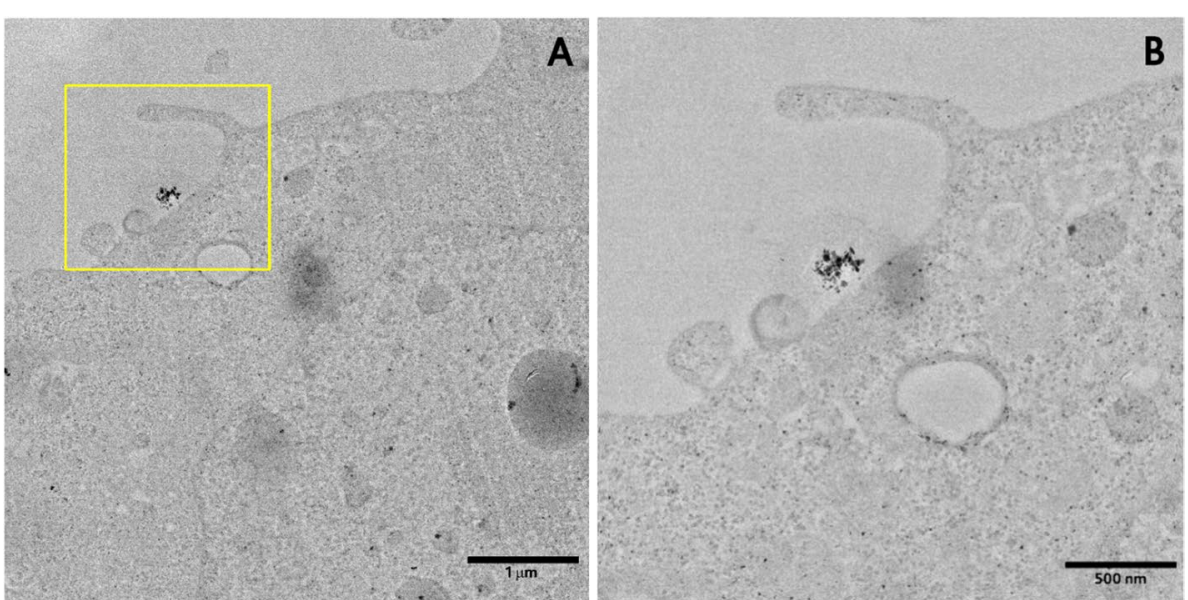

Fig. 7 PET-NPs engulfment by cells. TEM micrograph of macrophage and its response to PET nanoparticles at $24 \mathrm{~h}$. Image showed a cell membrane elongation (A) that is wrapping a PET nanoparticles conglomerate (B) 
flavonoids [49]. There is no information available on the methyltransferase's catalytic abilities of the RNA methyltransferase encoded by the MRM2 gene besides the methylation of mitochondrial rRNA. However, its role in the transformation of exogenous compounds, such as plastics, could not be a priori ruled out.

Another important finding was the evidence of PETNPs cell internalization. Even DLS results (Table 1) showed an agglomeration trend of nanoplastics (858 d.nm) in supplemented DMEM (media used for cell culture), TEM images showed dispersed particles inside of vesicles (Figs. 5F and 6) with particle sizes fewer than $200 \mathrm{~nm}$ (Fig. 6F2). Moreover, PET-NPs presence into cells has been clearly demonstrated when the interplanar distances of the PET-NPs samples (Fig. 1D) and PET-NPs internalized by macrophages cells (vesicles formed into the cytoplasm, observed as electrodense zones inside endosomes) were compared (Fig. 6F4). In both TEM images, the lattice periodicity measured was $0.34 \mathrm{~nm}$, correlated to (100) plane observed by XRD (Fig. 1F) and FFT (Fig. 1E), and already reported in the crystallographic table index (Reference code: 00-0600989) for pristine polyethylene terephthalate. The similar lattice periodicity in both, PET-NPs after fabrication and inside of cells, have demonstrated the high resistance and ultrastructure PET-NPs maintenance from their origin to cell internalization and superoxide radical's exposition until $72 \mathrm{~h}$.

On the other hand, cell internalization was corroborated by confocal images (Fig. 3) and TEM images (Fig. 5). In the first case, images showed the presence of PET-NPs into cells colocalized to ROS (yellow signal) and close to the nucleus (blue signal), whereas TEM images showed the presence of PET-NPs at 24, 48 and $72 \mathrm{~h}$ (Fig. 5). In addition, TEM micrographs have revealed that phagocytosis seems to be the mechanism for PET-NPs macrophage internalization, supported by the cell membrane elongation that wraps the nanoparticles clusters (200 $\mathrm{nm}$ of diameter) as observed in Fig. 7 and the presence of particles into vesicles (Fig. 6F1). Interestingly, our results showed another evidence that could be related to that mechanism, the upregulation of ROBO1 gene, which is the receptor of SLIT2 protein (SLITS2/ROBO1). This signaling has been related to recruitment, adhesion and immune activation of macrophages and monocytes by actin cytoskeleton rearrangement.

Additionally, the increment in SLITS2 decreased macropinocytosis and vice versa, an essential function of macrophages [30]. ROBO1 has shown to act as SLIT2 antagonist [30], while our data showed an increase of ROBO1 expression but not of SLIT2 gene. Thus, the increment in ROBO1 gene matches with the TEM
Table 1 Hydrodynamic diameter (Size) and Zeta Potential of PET-NPs in different media

\begin{tabular}{lcl}
\hline Solvent & Size $(\mathbf{d} . \mathbf{n m})$ & Zeta Potential \\
\hline Water + 0.5\% SDS & $221 \pm 56$ & $-47.5 \pm 1$ \\
Water (Milli Q) & $2660 \pm 173$ & $3.6 \pm 2$ \\
DMEM & $1197 \pm 18$ & $-18.4 \pm 1.6$ \\
FBS & $631 \pm 57$ & $-3.5 \pm 0.1$ \\
Supplemented DMEM & $858 \pm 38$ & $-12.3 \pm 1$ \\
\hline
\end{tabular}

observations, in which macropinocytosis seems to be the mechanism involved in the uptake of PET-NPs by macrophages.

However, the engulfment of nanoparticles is a more complex process because this mechanism is related also to nanoparticles' surface properties. Then, the interaction of PET-NPs with cell culture media was evaluated. DLS results showed that PET-NPs have agglomerated and have presented a negative charge after resuspension in DMEM, FBS and supplemented DMEM media. Although these results showed the influence of media in PET-NPs agglomeration, these data don't be enough to elucidate the composition of corona formed around PET-NPs, due to the composition complexity of cell culture media. According to Francia and colleagues [50], corona could be involved in cell internalization. Then, more experiments need to be performed in order to analyze the corona formation around PET-NPs, and its influence on cell engulfment.

Nevertheless, once small PET-NPs clusters are internalized (Fig. 7), the vesicle formed inside cells, reveals an individual particle phagosome, that is easily observed at $72 \mathrm{~h}$ (Fig. 6F1 and F2).

Despite PET-NPs internalization into the macrophage cells (Figs. 3, 5 and 6), the metabolic activity of the cell seems to be increased, with a slight increment to ROS production inside the cells, especially at $15 \mathrm{~g} / \mathrm{mL}$ (Fig. 2C). It is well known that ROS production is a general response of cells to the presence of nanoparticles [51, 52], especially metal nanoparticles. ROS is essential for different biological processes, such as gene expression, protein translation and post-translational modifications. However, recently the ROS production in the lumen phagosomes has been related to antigen presentation at low but prolonged ROS generation rates $[53,54]$. In this work, ROS production in macrophages showed a low but sustained increment production until $72 \mathrm{~h}$ (Fig. 2C). Moreover, the confocal images revealed that ROS production was directly related to the presence of PET-NPs (Fig. 3) as evidenced by colocation (yellow) of PET-NPs signal (red) and DCF signal (green). Thus, in contrast to common knowledge related to the macrophages' 
efficiency to eliminate antigens by ROS production and phagosomes maturation, our results suggest that ROS production seems to be more related to particle recognition as foreign material.

The macrophage response observed which includes ROS generation increment (Fig. 3) and gene upregulation (Fig. 2D), can be associated directly with PETNPs (Fig. 5). The upregulated genes were IGHV10 and PCHD12. IGHV10 is an immunoglobulin variable heavy chain from V10 family, which is frequently found in DNA-binding antibodies. Interestingly, this transcript appears to make an excessively large contribution to the pre-immune B cell repertoire [55]. IGHV genes family have been related to antigens driven process [56] because of $\mathrm{V}$ region that is involved in antigen recognition [57], and its expression are the result of an adaptive response of macrophages to antigens [58]. On the other hand, PCDH12 encodes a protocadherin 12 protein (belongs to the largest cadherin subfamily). Protocadherin is also a cell adhesion molecule, the reduced expression of which affects cell-cell adhesion and structural integrity in the striatum [59]. In addition, it can be speculated that immunoglobulin similar recognize activity from protocadherin, because of analogy to variable and constant domains to immunoglobulins [60].

In summary, PET-NPs obtained from the dilution and precipitation procedure, let to achieve nanoparticles ('250 d.nm) which maintains the ultrastructure and the chemical composition from their origin (Fig. 1E) and consistent to pristine material (Fig. 1F). PET-NPs concentrations between $10-100 \mu \mathrm{g} / \mathrm{mL}$ have an effect in cell proliferation, determined by resazurin reduction, with the highest effect at $15 \mu \mathrm{g} / \mathrm{mL}$. PET-NPs-macrophages in vitro interaction starts with plastic nanoparticle recognition as foreign particle and its cell internalization by macropinocytosis. Once inside, the small nanoplastic cluster is separated into individual vesicles (phagosomes), accompanied by low but maintained ROS production, that seems to induce gene expression and post-translational modification to FTSJ2 $(\log 2=5.2)$, IGH-V10 $(\log 2=2.0)$, ROBO1 $(\log 2=2.2)$ and PCDH12 $(\log 2=2.5)$. These genes have been associated with different cell functions, such as the recruitment, adhesion, and immune activation of macrophages (ROBO1); with driving the foreign particle and antigen recognition (IGH-V10); to be a cell adhesion molecule (PCDH12) with similar recognize activity that immunoglobulins, and with a nucleolar and conserved family of RNA methyltransferase (FTSJ2 also identified as MRM2).

These preliminary findings would let to integrate some mechanisms and assess metabolic features, which are critical for macrophages activation, independently to the route of nanoplastics internalization, given some directions about future work in more complex systems, tissues and organisms. Thus, it is very important to continue assessing the effect of micro and nanoplastics on different cells (lines, primary, and mesenchymal stem cells), as well as to evaluate the complete role of SLIT2/ ROBO1 signaling, corona formed characterization and proteins associated with the cell engulfment PET-NPs process, necessaries to enlarge and enrich the knowledge about their effects in cell physiology, in order to determine specific endpoints that must be evaluated in future in vivo studies.

\section{Conclusion}

This work shows that PET-NPs obtained for dilution and precipitation technique, have maintained the composition and chemical structure of the original material. $15 \mu \mathrm{g} / \mathrm{mL}$ of PET-NPs seems to be a critical concentration that showed an effect on macrophage cells physiology affecting cell proliferation. The presence of PET-NPs into cell vesicles seems to be related with cell-internalized by macropinocytosis, and to trigger some responses as foreign particles, related to upregulation of IGH-V10, ROBO1 and PCDH12 genes. Additionally, macrophages showed a slight and constant ROS production that could promote the induction to the gene expression and posttranslational modification of FTSJ2 (also MRM2), which could be associated with cell maintenance in response to PET-NPs presence. Interestingly, the mitochondrial RNA methyltransferase encoded by MRM2 has been found structurally equivalent to the catechol-O-methyltransferase. This enzyme is involved in the transformation of exogenous phenolic compounds. Nevertheless, the catalytic role of the protein from MRM2 in the degradation of PET nanoparticles is not yet elucidated and more experiments are necessary to assess that involvement.

\section{Experimental methods \\ PET-NPs production and characterization}

The PET nanoparticles were obtained as previously reported [24]. Commercial PET bottles were used to produce fine debris by abrasion, which were sieved to obtain the fines fraction ( $\left.{ }^{\circ} 200 \mu \mathrm{m}\right)$. One gram was dissolved in $10 \mathrm{~mL}$ of trifluoroacetic acid (TFA $90 \% \mathrm{v} / \mathrm{v}$ ), stirred at $50{ }^{\circ} \mathrm{C}$ for $2 \mathrm{~h}$ until total dissolution and kept overnight at room temperature. Finally, $10 \mathrm{~mL}$ of TFA $(20 \% \mathrm{v} / \mathrm{v})$ were added for nanoparticles precipitation. The size and morphology of PET-NPs were determined by HRTEM on a FEI Tecnai G2 F20 S-TWIN microscope. X-ray diffraction analysis to assess the structural characteristics of the nanoparticles was performed with a Panalytical X'Pert MRD Pro diffractometer with a $\mathrm{Cu} \mathrm{K} \alpha \mathrm{X}$-ray source and equipped with an X'Celerator detector. Fourier transform infrared (FTIR) was performed on both the obtained 
PET-NPs and material reference (PET bottle). Spectra were taken from $500-3100 \mathrm{~cm}^{-1}$ range, accumulating 32 scans and $2 \mathrm{~cm}^{-1}$ of resolution. PET-NPS solution in $0.5 \%$ SDS ( $3 \mathrm{~mL}$ ) with a final concentration of $400-500 \mathrm{mg} / \mathrm{L}$, were analysed by Asymmetrical Flow Field-Flow Fraction (A4F) (Postnova Analytics $\mathrm{GmbH}$ ) for nanoparticles size distribution obtained after precipitation. For cell culture assays, nanoparticles with dimensions up to $250 \mathrm{~nm}$ were separated from the original precipitation. The whole original PET solution was resuspended in $1 \mathrm{~L}$ of $0.5 \%$ sodium dodecyl sulfate (SDS), ultrasonicated (Vibra $\mathrm{Cell}^{\mathrm{TM}}$ VCX 600, Sonics \& Materials Inc), and was allowed to settle in a cylinder for $1 \mathrm{~h}{ }^{(17)}$. Different samples from the cylinder were again measured by DLS (Zetasizer Nanoseries, Nano-ZS, Malvern Instruments) and the top section containing the nanosized PET (50-250 nm) was recovered, washed twice with ultrapure water and absolute ethanol by centrifugation ( $3500 \mathrm{rpm}, 30 \mathrm{~min}, 4{ }^{\circ} \mathrm{C}$ ), and dried under the fume hood for further experiments. Additionally, $1 \mu \mathrm{g}$ of PET-NPs was resuspended in different media (ultrapure water, Dulbecco's Modified Eagle Medium (DMEM), Foetal Bovine Serum (FBS) and supplemented Dulbecco's Modified Eagle Medium, and their hydrodynamic diameter and zeta potential were measured by DLS.

\section{Cell line and cell culture}

To assess the toxicological effects of PET-NPs, RAW 264.7 macrophages cell line $\left(\right.$ ATCC $^{\circledR}$ TIB- $1^{\mathrm{TM}}$ ) was selected. Cells were routinely maintained and cultured in Dulbecco's Modified Eagle Medium (DMEM) from Sigma-Aldrich, supplemented with $10 \%$ Foetal Bovine Serum (FBS) from Biowest, $1 \%$ penicillin-streptomycin (Sigma-Aldrich), 1\% L-glutamine, and $3.7 \mathrm{~g} / \mathrm{L}$ sodium bicarbonate, under a humidified atmosphere $\left(5 \% \mathrm{CO}_{2}\right)$ at $37^{\circ} \mathrm{C}$.

\section{Cell viability assay}

Viability tests were carried out in 96-well plates with RAW264.7. Cells at $80 \%$ of confluence, were previously seeded overnight before the experiment at a density of $1.5 \times 10^{4}$ cells/well. For cell cultures, a stock PET-NPs solution $(10 \mathrm{mg} / \mathrm{mL})$ was prepared in supplemented DMEM. Then cells were exposed to different PET-NPs concentrations $(0.1 \mu \mathrm{g} / \mathrm{mL}, 1 \mu \mathrm{g} / \mathrm{mL}, 10 \mu \mathrm{g} / \mathrm{mL}, 100 \mu \mathrm{g} /$ $\mathrm{mL}, 1 \mathrm{mg} / \mathrm{mL}$ and $10 \mathrm{mg} / \mathrm{mL}$ ) during 24,48 , and $72 \mathrm{~h}$ at $37^{\circ} \mathrm{C}$. Each sample was assayed by triplicate, and DMSO was used as a negative control for viability. After incubation time, the medium was replaced by AlamarBlue reagent (TermoFisher SCIENTIFIC) diluted 1:10 (v/v) with DMEM and incubated for $4 \mathrm{~h}$ at $37^{\circ} \mathrm{C}$ and $5 \% \mathrm{CO}_{2}$. Then, supernatants were transferred into a new 96-well plate, and the samples were measured using the automated fluorescence reader Agilent Cary Eclipse at 530/585 nm (Excitation/Emission). A sharper range of PET-NPs concentrations $(7.5,15,30$ and $60 \mathrm{~g} / \mathrm{mL})$, was also assayed under the same conditions. Additionally, cells were detached from wells and counted using a Neubauer chamber.

\section{Detection of reactive oxygen species (ROS)}

The generation of hydrogen peroxide and superoxide radicals as a measurement of cell response to PET-NPs, was monitored by employing DCFDA (Abcam) staining. DCFDA is a non-fluorescent compound in the reduced form, which upon oxidation by ROS, becomes DCF and emits green fluorescence. ROS production assay was carried out in 24-well plates with RAW264.7 cells seeded one day before the experiment at a density of $1.5 \times 10^{4}$ cells/well. Then, they were washed with $1 \times$ phosphatebuffered saline $(1 \times$ PBS $)$ and exposed to DCFDA $(17 \mu \mathrm{M})$ for 30 min under dark in a humidified atmosphere $(5 \%$ $\mathrm{CO}_{2}$ ) at $37^{\circ} \mathrm{C}$. The plate was rewashed with PBS and cells were exposed with PET-NPs $(7.5,15,30$, and $60 \mathrm{~g} / \mathrm{mL})$ for 24,48 , and $72 \mathrm{~h}$ at $37^{\circ} \mathrm{C}$. Each sample was assayed by triplicate, and $50 \mathrm{M} \mathrm{TBHP}$ was used as a positive control of ROS production. The supernatants were transferred into a 96-well plate, and the samples were measured using the automated fluorescence reader Agilent Cary Eclipse at 485/535 nm (excitation/emission).

\section{Detection of ROS production by confocal microscopy}

DCFDA staining let to observe the cell localization of ROS production, thus cells incubated with PET-NPs were prepared to be analyzed by confocal microscope. Previously one $\mathrm{mL}$ of PET-NPs was stained by mixing with Nile Red (NR) according to a previously reported protocol [24]. Coverslip pre-coated with poly-L-lysine, were used to seed $1 \times 10^{4}$ cells, and incubated overnight at $37{ }^{\circ} \mathrm{C}$ with $5 \% \mathrm{CO}_{2}$. Then, the cells were washed with $1 \times$ phosphate-buffered saline $(1 \times \mathrm{PBS})$ and exposed to DCFDA $(17 \mu \mathrm{M})$ for 30 min under darkness and humidified atmosphere $\left(5 \% \mathrm{CO}_{2}\right)$ at $37^{\circ} \mathrm{C}$. RAW 264.7 cells were incubated with labelled PET-NPs-NR $(15 \mu \mathrm{g} / \mathrm{mL})$ for 24 , 48 , and $72 \mathrm{~h}$ at $37{ }^{\circ} \mathrm{C}$ under $5 \% \mathrm{CO}_{2}$ atmosphere. Then, cells were rinsed with $1 \times$ PBS and fixed with methanol at $-20{ }^{\circ} \mathrm{C}$ for $20 \mathrm{~min}$. After fixation, cells were permeabilized with $0.3 \%$ Tween in $1 \times \mathrm{PBS}$ for $15 \mathrm{~min}$ at $4{ }^{\circ} \mathrm{C}$. Nuclear staining was achieved by incubating the cells with 4 DAPI at $0.5 \mathrm{ng} / \mathrm{mL}$ in darkness for 1 - $\mathrm{h}$ at $24{ }^{\circ} \mathrm{C}$. Previously, microscope slides and coverslips were washed with $1 \times$ PBS and fixed with glycerol.

Cell images were obtained with an inverted laser scanning microscope (Olympus FluoView FV1000), equipped with an Ar laser at $488 \mathrm{~nm}$ with GFP filters at 
515-530 nm, a laser diode (LD) laser for excitation at $405 \mathrm{~nm}$ with DAPI filters for emission at $455 \mathrm{~nm}$, and a red laser for excitation at $637 \mathrm{~nm}$ with Texas red filters for emission at $594 \mathrm{~nm}$. Confocal images were captured using the FV-10 ASW software and were analysed with the FV-10ASW viewer version 4.1 from Olympus.

\section{Mitochondrial observation}

In order to observe the damage of mitochondria after incubation with PET-NPs, six coverslip pre-coated with poly-L-lysine, were used to seed $1 \times 10^{4}$ cells, and incubated overnight at $37{ }^{\circ} \mathrm{C}$ with $5 \% \mathrm{CO}_{2}$. Then, an aliquot of PET-NPs was added to 3 coverslips (final concentration $15 \mu \mathrm{g} / \mathrm{mL}$ ) and all samples were incubated for 24 , 48 and $72 \mathrm{~h}$ at $37{ }^{\circ} \mathrm{C}$ with $5 \% \mathrm{CO}_{2}$. After time of incubation, coverslips were fixed with glutaraldehyde (2.5\%) for $30 \mathrm{~min}$ and $4{ }^{\circ} \mathrm{C}$, washed twice with $1 \times$ PBS and permeabilized with $0.3 \%$ Tween in $1 \mathrm{X}$ PBS for $15 \mathrm{~min}$, then $100 \mu \mathrm{L}$ of Double Detection Reagent Mito-ID (Enzo) was added and incubated $37^{\circ} \mathrm{C}$ for $30 \mathrm{~min}$, washed twice with $1 \times$ PBS and observed with Olympus FluoView FV1000 Confocal Microscope. Images were analyzed with the FV-10ASW viewer version 4.1 from Olympus.

\section{Statistical analysis}

Statistical analyses of all experiments were performed in three independent replicates with internal triplicates each. The results were expressed as mean \pm standard deviation of three independent experiments. Data were evaluated by analysis of variance, followed by Tukey's multiple comparison test using GraphPad Prism version 6.0c software. The results were considered statistically significant when $p<0.05$.

\section{Transmission electron microscopy (TEM)}

PET-NPs internalization was observed by transmission electron microscopy, in order to corroborate nanoparticles presence into macrophages after 24, 28 and $72 \mathrm{~h}$ of incubation. Cells were cultured in $6 \mathrm{~cm}$ treated Petri dishes (CytoOne) and incubated with PET-NPs $(15 \mu \mathrm{g} /$ $\mathrm{mL}$ ) for 24,48 , and $72 \mathrm{~h}$ at $37{ }^{\circ} \mathrm{C}$ under $5 \% \mathrm{CO}_{2}$ atmosphere. Then, the complete medium was removed, and cells were fixed by adding $1 \mathrm{~mL}$ of $4 \%$ glutaraldehyde $(\mathrm{v} / \mathrm{v})$ in $1 \times$ PBS to each plate and allowed to fix for $1 \mathrm{~h}$ at $4{ }^{\circ} \mathrm{C}$. The fixed samples were washed three times with $1 \times$ PBS. Cells were detached from Petri dishes with a scrapper, collected in a microfuge tube, centrifuged (250 g) for $5 \mathrm{~min}$, gently rinsed in ultrapure water, and postfixed for one hour with $1 \% \mathrm{OsO}_{4}(\mathrm{w} / \mathrm{v})$ in ultrapure water for about $2 \mathrm{~h}$ at room temperature (RT). The post-fixed cells were then washed with ultrapure water and dehydrated with ethanol solutions from 50 to $100 \%$. The cells were then infiltrated with a mixture of ethanol/Spurr epoxy resin (1969 Ted Pella. Inc, prd. No. 18300-4221 low viscosity kit) containing 15, 30, 50, 75 and $100 \%$ of resin for $4 \mathrm{~h}$ each. Then, samples were molded in Spurr resin and polymerized for $24 \mathrm{~h}$ at $60{ }^{\circ} \mathrm{C}$. Finally, ultrathin cuts were obtained with Ultracut $\mathrm{R}$ ultramicrotome (Leica Microsystems) using a glass knife. The ultrathin sections were placed on copper TEM grids (300 mesh) and then were observed and analyzed on Tecnai G2 F20 S-Twin (FEI) transmission electron microscope using $80 \mathrm{kV}$ as the accelerating voltage.

\section{Microarray analysis}

To assess the effects in cell physiology, microarrays of macrophages incubated with and without PET-NPs were performed and analyzed. $1 \times 10^{7}$ cells were cultured in $10 \mathrm{~cm}$ plates and incubated with and without PET-NPs $(15 \mu \mathrm{g} / \mathrm{mL})$ for $48 \mathrm{~h}$ at $37{ }^{\circ} \mathrm{C}$ under $5 \% \mathrm{CO}_{2}$ atmosphere. Total RNA was extracted by direct addition of TRI Reagent (Sigma-Aldrich). Following the chloroform $(0.2 \mathrm{~mL} / 1 \mathrm{~mL}$ of TRI Reagent) and centrifugated for $15 \mathrm{~min}$ at $12,000 \mathrm{~g}$ at $4{ }^{\circ} \mathrm{C}$. Isopropanol $(0.5 \mathrm{~mL})$ was added to the supernatant and centrifugated for $15 \mathrm{~min}$ at $12,000 \mathrm{~g}$ at $4{ }^{\circ} \mathrm{C}$. Then, $1 \mathrm{~mL}$ of $75 \%$ ethanol was added to the supernatant and centrifugated for $5 \mathrm{~min}$ at 7,500 g at $4{ }^{\circ} \mathrm{C}$. Diethyl pyrocarbonate was added to protect ARN. Finally, RNA was quantified using the NanoDrop 2000/2000c. Microarray hybridization was performed and analyzed by genArise software, at the Cellular Physiology Institute, UNAM, Mexico City. The microarray datasets generated using the custom designed Mus musculus oligonucleotide array containing 65-mer probe sets representing 22,000 transcripts) were analyzed. Ten $\mu \mathrm{g}$ of total RNA were used for cDNA synthesis incorporating dUTP-Alexa555 or dUTP-Alexa647 employing the CyScribe First-Strand cDNA labelling kit (Amersham). The incorporation of the fluorophore was analysed by absorbance at $555 \mathrm{~nm}$ for Cy3 (Control) and $655 \mathrm{~nm}$ for Cy5 (Cells in presence of PET-NPs). Equal quantities of labelled cDNA were hybridized using hybridization solution HybIT2 (TeleChem International INC). The arrays were incubated for $14 \mathrm{~h}$ at $42{ }^{\circ} \mathrm{C}$ and then washed three times with one $\times \mathrm{SCC}, 0.05 \% \mathrm{SDS}$ at room temperature. Cy3 labelling was used for RNA of control macrophages while Cy5 labelling was used for and macrophages exposed to PET-NPs. Acquisition and quantification of array images were performed in ScanArray 4000 with its accompanying software ScanArray 4000 from Packard BioChips. All images were captured using a 65\% PMT gain, 70 to $75 \%$ laser power, and $10 \mu \mathrm{m}$ resolution at $50 \%$ scan rate. For each spot, the Cy3 and Cy5 density mean values, and the Cy3 and Cy5 background mean values were calculated with the software ArrayPro Analyzer from Media Cybernetics. Quantile normalization and 
subsequent data processing were performed using the $\mathrm{R}$ software package. Hierarchical clustering was performed to show the distinguishable RNA expression pattern among samples.

\begin{abstract}
Abbreviations
PET: Polyethylene terephthalate; PET-NPs: PET nanoparticles; ROS: Reactive Oxygen Species; MPs: Microplastics; NPs: Nanoplastics; TEM: Transmission electron Microscopy; HRTEM: High-Resolution Transmission Electron Microscopy; XRD: X-ray diffraction; SDS: Sodium dodecyl sulfate; A4F: Asymmetrical flow field-flow fractionation; DCFDA: 2',7'-Dichlorodihydrofluorescein diacetate; DCF: 2,7'-Dichlorofluorescein; PET-NPs-NR: PET nanoparticles- Nile Red; DMEM: Dulbecco's Modified Eagle Medium; FBS: Foetal Bovine Serum; DMSO: Dimethyl sulfoxide; TBHP: Tert-butyl hydroperoxide; PBS: Phosphate-buffered saline; DAPI: 4',6-Diamidino-2-phenylindole; NR: Nile Red; RT: Room temperature.
\end{abstract}

\section{Acknowledgements}

The National Council of Science and Technology of Mexico (CONACyT) financed this manuscript, under SINANOTOX project (PN-2017-01-4710). AGRH is a fellow "Catedrático CONACYT" under project 53. A personal and particular thanks to Dr. Alejandro Munoz-Tabares for his valuable comments and discussion and Dr Angelica Chiodoni for their TEM support, comments, and friendship. We would like to thank Katrin Quester for her technical support.

\section{Authors' contributions}

Conceptualization, A.R.H. and R.V.D.; methodology, A.R.H., E.V.J and R.V.D.; formal analysis, A.R.H.; investigation, J.C.A.G., A.M.V. and A.R.H.; data curation, A.R.H. and R.V.D.; writing original draft preparation, A.R.H. and R.V.D; writing review and editing, A.R.H. and R.V.D; funding acquisition, R.V.D. All authors have read and agreed to the published version of the manuscript.

\section{Funding}

The National Council of Science and Technology of Mexico (CONACyT) financed this manuscript, under SINANOTOX project (PN-2017-01-4710). AGRH is a fellow "Catedrático CONACyT" under project 53.

\section{Availability of data and materials}

Not applicable.

\section{Declarations}

\section{Competing interest}

The authors declare that they have no known competing financial interests or personal relationships that could have appeared to influence the work reported in this paper.

\section{Author details \\ ${ }^{1}$ Center for Nanosciences and Nanotechnology, Universidad Nacional Autónoma de México, Ensenada, B.C, México. ${ }^{2}$ Center for Sustainable Future Technologies - Istituto Italiano Di Tecnologia, via Livorno, 60-10144 Torino, Italy. ${ }^{3}$ School of Geography, Earth and Environmental Sciences, University of Birmingham, Edgbaston, Birmingham B15 2TT, UK. ${ }^{4}$ CATEDRA CONACyT Researcher at CNYN -UNAM, Ensenada, Baja California, México.}

Received: 24 July 2021 Accepted: 10 January 2022

Published online: 23 February 2022

\section{References}

1. Shen M, Zhu Y, Zhang Y, Zeng G, Wen X, Yi H, Shujing Y, Ren X, Song B. Micro(nano)plastics: Unignorable vectors for organisms. Mar Pollut Bull. 2019;139:328-31. https://doi.org/10.1016/j.marpolbul.2019.01.004.

2. Statista https://www.statista.com/statistics/1245264/polyethylene-terep hthalate-market-volume-worldwide/

3. Koelmans AA, Mohamed Nor NH, Hermsen E, Kooi M, Mintenig SM, De France J. Microplastics in freshwaters and drinking water: Critical review and assessment of data quality. Water Res. 2019;155:410-22. https://doi. org/10.1016/j.watres.2019.02.054.

4. Lu S, Qiu R, Hu J, Li X, Chen Y, Zhang X, He D. Prevalence of microplastics in animal-based traditional medicinal materials: Widespread pollution in terrestrial environments. Sci Total Environ. 2020;709:136214. https://doi. org/10.1016/j.scitotenv.2019.136214

5. Yin L, Jiang C, Wen X, Du C, Zhong W, Feng Z, Ma Y. Microplastic pollution in surface water of urban lakes in Changsha, China. Int J Environ Res Public Health. 2019;16(9). https://doi.org/10.3390/ijerph16091650

6. RW Obbard 2018 Microplastics in Polar Regions: The role of long range transport https://doi.org/10.1016/j.coesh.2017.10.004

7. Li J, Yang D, Li L, Jabeen K, Shi H. Microplastics in commercial bivalves from China. Environ Pollut. 2015;207:190-5. https://doi.org/10.1016/j. envpol.2015.09.018.

8. Zhang Y, Kang S, Allen S, Allen D, Gao T, Sillanpää M. Atmospheric microplastics: A review on current status and perspectives. Earth Sci Rev. 2020;203:103118. https://doi.org/10.1016/j.earscirev.2020.103118.

9. Pennino MG, Bachiller E, Lloret-Lloret E, Albo-Puigserver M, Esteban A Jadaud A, Bellido JM, Coll M. Ingestion of microplastics and occurrence of parasite association in Mediterranean anchovy and sardine. Marine Pollution Bulletin. 2020;158:111399. https://doi.org/10.1016/j.marpolbul.2020. 111399.

10. Kasamesiri $P$, Thaimuangpho W. Microplastics ingestion by freshwater fish in the chi river, Thailand. Int J GEOMATE. 2020;18(67):114-9. https://doi. org/10.21660/2020.67.9110

11. Ragusa A, Svelato A, Santacroce C, Catalano P, Notarstefano V, Carnevali O, Papa F, Rongioletti MCA, Baiocco F, Draghi S, D'Amore E, Rinaldo D, Matta M, Giorgini E. Plasticenta: First evidence of microplastics in human placenta. Environment International. 2021;146:106274. https://doi.org/10. 1016/j.envint.2020.106274.

12. Zhang J, Wang L, Trasande L, Kannan K. Occurrence of Polyethylene Terephthalate and Polycarbonate Microplastics in Infant and Adult Feces. Environ Sci Technol Lett. 2021;8(11):989-94. https://doi.org/10.1021/acs. estlett.1c00559.

13 Rubio L, Marcos R, Hernández A. Potential adverse health effects of ingested micro- and nanoplastics on humans. Lessons learned from in vivo and in vitro mammalian models. J Toxicol Environ Health B Crit Rev. 2020;23(2):51-68. https://doi.org/10.1080/10937404.2019.1700598.

14. Lee H, Kunz A, Shim WJ, Walther BA. Microplastic contamination of table salts from Taiwan, including a global review. Sci Rep. 2019;9(1):10145. https://doi.org/10.1038/s41598-019-46417-z.

15. Wong SL, Nyakuma BB, Wong KY, Lee CT, Lee TH, Lee CH. Microplastics and nanoplastics in global food webs: A bibliometric analysis (20092019). Mar Pollut Bull. 2020;158:111432. https://doi.org/10.1016/j.marpo Ibul.2020.111432.

16. Diaz-Basantes MF, Conesa JA, Fullana A. Microplastics in honey, beer, milk and refreshments in Ecuador as emerging contaminants. Sustainability (Switzerland). 2020;12(12):5514. https://doi.org/10.3390/SU12145514.

17. Hernandez LM, Xu EG, Larsson HCE, Tahara R, Maisuria VB, Tufenkji N. Plastic Teabags Release Billions of Microparticles and Nanoparticles into Tea. Environ Sci Technol. 2019;53(21):12300-10. https://doi.org/10.1021/ acs.est.9b02540.

18. Barboza LGA, Dick Vethaak A, Lavorante BRBO, Lundebye AK, Guilhermino L. Marine microplastic debris: An emerging issue for food security, food safety and human health. Mar. Pollut. Bull. Elsevier Ltd. 2018. https://doi. org/10.1016/j.marpolbul.2018.05.047

19. De-la-Torre GE. Microplastics: an emerging threat to food security and human health. J. Food Sci. Technol. Springer. 2020. https://doi.org/10. 1007/s13197-019-04138-1

20. Van Cauwenberghe $L$, Janssen CR. Microplastics in bivalves cultured for human consumption. Environ Pollut. 2014;193:65-70. https://doi.org/10. 1016/j.envpol.2014.06.010.

21. Mohamed Nor NH, Kooi M, Diepens NJ, Koelmans AA. Lifetime accumulation of microplastic in children and adults. Environ Sci Technol. 2021;55(8):5084-96. https://doi.org/10.1021/acs.est.0c07384.

22. Senathirajah K, Attwood S, Bhagwat G, Carbery M, Wilson S, Palanisami T. Estimation of the mass of microplastics ingested-A pivotal first step towards human health risk assessment. J Hazard Mater. 2021;404:124004. https://doi.org/10.1016/j.jhazmat.2020.124004.

23. Magrì D, Sánchez-Moreno P, Caputo G, Gatto F, Veronesi M, Bardi G, Fragouli D. Laser Ablation as a Versatile Tool To Mimic Polyethylene 
Terephthalate Nanoplastic Pollutants: Characterization and Toxicology Assessment. ACS Nano. 2018;12(8):7690-700. https://doi.org/10.1021/ acsnano.8b01331.

24. Rodríguez-Hernández AG, Muñoz-Tabares JA, Aguilar-Guzmán JC, Vazquez-Duhalt R. A novel and simple method for polyethylene terephthalate (PET) nanoparticle production. Environ Sci Nano. 2019;6(7):20316. https://doi.org/10.1039/c9en00365g.

25. Ida F, Ramasubbu S, Mukherjee A, Chandrasekaran N. Polystyrene nanoplastics dysregulate lipid metabolism in murine macrophages in vitro. Toxicology. 2021;458:152850. https://doi.org/10.1016/j.tox.2021.152850.

26. Wu B, Wu X, Liu S, Wang Z, Chen L. Size-dependent effects of polystyrene microplastics on cytotoxicity and efflux pump inhibition in human Caco-2 cells. Chemosphere. 2019;221:333-41. https://doi.org/10.1016/j. chemosphere.2019.01.056.

27. Schirinzi GF, Pérez-Pomeda I, Sanchís J, Rossini C, Farré M, Barceló D. Cytotoxic effects of commonly used nanomaterials and microplastics on cerebral and epithelial human cells. Environ Res. 2017;159:579-87. https://doi.org/10.1016/j.envres.2017.08.043.

28. Prietl B, Meindl C, Roblegg E, Pieber TR, Lanzer G, Fröhlich E. Nano-sized and micro-sized polystyrene particles affect phagocyte function. Cell Biol Toxicol. 2014;30:1-16. https://doi.org/10.1007/s10565-013-9265-y.

29. Bordbar A, Mo ML, Nakayasu ES, Schrimpe-Rutledge AC, Kim Y-M, Metz TO, Jones MB, Frank BC, Smith RD, Peterson SN, Hyduke DR, Adkins JN, Palsson BO. Model-driven multi-omic data analysis elucidates metabolic immunomodulators of macrophage activation. Mol Syst Biol. 2012;8:558. https://doi.org/10.1038/msb.2012.21.

30. Bhosle VK, Mukherjee T, Huang YW, Patel S, Pang BW, Liu GY, Robinson LA. SLIT2/ROBO1-signaling inhibits macropinocytosis by opposing cortical cytoskeletal remodeling. Nat Commun. 2020;11(1):4112. https://doi.org/ 10.1038/541467-020-17651-1.

31. Soukup J, Becker S. Human alveolar macrophage responses to air pollution particulates are associated with insoluble components of coarse material, including particulate endotoxin. Toxicol Appl Pharmacol. 2001;171(1). https://doi.org/10.1006/TAAP.2000.9096

32. Han X, Ding S, Jiang H, Liu G. Roles of Macrophages in the Development and Treatment of Gut Inflammation. Front Cell Dev Biol. 2021;9:625423. https://doi.org/10.3389/fcell.2021.625423.

33. De Schepper S, Verheijden S, Aguilera-Lizarraga J, Viola MF, Boesmans W, Stakenborg N, Voytyuk I, et al. Self-Maintaining Gut Macrophages Are Essential for Intestinal Homeostasis. Cell. 2018;175:400-15. https://doi. org/10.1016/j.cell.2018.07.048

34. Ji W, Wei-Dong C, Yan-Dong W. The Relationship Between Gut Microbiota and Inflammatory Diseases: The Role of Macrophages. Front Microbiol. 2020;11:1065. https://doi.org/10.3389/fmicb.2020.01065.

35. Viola MF, Boeckxstaens G. Intestinal resident macrophages: Multitaskers of the gut. Neurogastroenterol Motil. 2020;32:e13843. https://doi.org/10. $1111 / \mathrm{nmo} .13843$

36. Fu W, Min J, Jiang W, Li Y, Zhang W. Separation, characterization and identification of microplastics and nanoplastics in the environment. Sci Total Environ. 2020;721:137561. https://doi.org/10.1016/j.scitotenv.2020 137561

37. Halle AT, Jeanneau L, Martignac M, Jardé E, Pedrono B, Brach L, Gigault J. Nanoplastic in the North Atlantic Subtropical Gyre. Environ Sci Technol. 2017;51(23):13689-97. https://doi.org/10.1021/acs.est.7b03667.

38 Lionetto F, Corcione CE, Rizzo A, Maffezzoli A. Production and Characterization of Polyethylene Terephthalate Nanoparticles. Polymers. 2021;13(21):3745. https://doi.org/10.3390/polym13213745 (MDPI AG)

39. Foetisch A, Filella M, Watts B, Vinot LH, Bigalke M. Identification and characterisation of individual nanoplastics by scanning transmission X-ray microscopy (STXM) J Hazard Mater. 2021;127804. https://doi.org/10. 1016/j.jhazmat.2021.127804

40. Chen Z, Hay JN, Jenkins MJ. FTIR spectroscopic analysis of poly (ethylene terephthalate) on crystallization. Eur Polymer J. 2012;48(9):1586-610. https://doi.org/10.1016/j.eurpolymi.2012.06.006.

41. Aleshin VA, Artiukhov AV, Oppermann H, Kazantsev AV, Lukashev NV, Bunik VI. Mitochondrial Impairment May Increase Cellular NAD(P)H: Resazurin Oxidoreductase Activity, Perturbing the NAD(P)H-Based Viability Assays. Cells. 2015;4(3):427-51. https://doi.org/10.3390/cells4030427.

42. Ching YP, Zhou HJ, Yuan JG, Qiang BQ, Kung HF, Jin DY. Identification and characterization of FTSJ2, a novel human nucleolar protein homologous to bacterial ribosomal RNA methyltransferase. Genomics. 2002;79(1):2-6. https://doi.org/10.1006/geno.2001.6670.

43. Dimitrova DG, Teysset L, Carré C. RNA 2'-O-Methylation (Nm) modification in human diseases. Genes. 2019;10(2):117. https://doi.org/10.3390/ genes10020117.

44. Liu B, Li J, Zheng M, Ge J, Li J, Yu P. MiR-542-3p exerts tumor suppressive functions in non-small cell lung cancer cells by upregulating FTSJ2. Life Sci. 2017;188:87-95. https://doi.org/10.1016/j.lfs.2017.08.018.

45. Rorbach J, Boesch P, Gammage PA, Nicholls TJJ, Pearce SF, Patel D, Minczuk M. MRM2 and MRM3 are involved in biogenesis of the large subunit of the mitochondrial ribosome. Mol Biol Cell. 2014;25(17):2542-55. https://doi.org/10.1091/mbc.e14-01-0014.

46. Bügl H, Fauman EB, Staker BL, Zheng F, Kushner SR, Saper MA, Jakob U. RNA methylation under heat shock control. Mol Cell. 2000;6(2):349-60. https://doi.org/10.1016/S1097-2765(00)00035-6.

47. Kleywegt GJ, Jones TA. Detecting folding motifs and similarities in protein structures. Method Enzymol. 1997;277:525-45. https://doi.org/10.1016/ S0076-6879(97)77029-0.

48. Jalkanen A, Lassheikki V, Torsti T, Gharib E, Lehtonen M, Juvonen RO. Tissue and interspecies comparison of catechol- $\mathrm{O}$-methyltransferase mediated catalysis of 6- O -methylation of esculetin to scopoletin and its inhibition by entacapone and tolcapone. Xenobiotica. 2020:1-11. https:// doi.org/10.1080/00498254.2020.1853850

49. Männistö PT, Kaakkola S. Catechol-O-methyltransferase (COMT): biochemistry, molecular biology, pharmacology, and clinical efficacy of the new selective COMT inhibitors. Pharmacol Rev. 1999;51(4):593-628 (PMID: 10581325).

50. Francia V, Yang K, Deville S, Reker-Smit C, Nelissen I, Salvati A. Corona composition can affect the mechanisms cells use to internalize nanoparticles. ACS Nano. 2019;13(10):11107-21. https://doi.org/10.1021/acsnano. 9b03824.

51. Makhdoumi P, Karimi H, Khazaei M. Review on Metal-Based Nanoparticles: Role of Reactive Oxygen Species in Renal Toxicity. Chem Res Toxicol. 2020;33(10):2503-14. https://doi.org/10.1021/acs.chemrestox.9b00438.

52. Yu Z, Li Q, Wang J, Yu Y, Wang Y, Zhou Q, Li P. Reactive Oxygen SpeciesRelated Nanoparticle Toxicity in the Biomedical Field. Nanoscale Res Lett. 2020;15(1):115. https://doi.org/10.1186/s11671-020-03344-7.

53. Kotsias F, Hoffmann E, Amigorena S, Savina A. Reactive Oxygen Species Production in the Phagosome: Impact on Antigen Presentation in Dendritic Cells. Antioxid Redox Signal. 2013;18(6):714-29. https://doi.org/10. 1089/ars.2012.4557.

54. Paardekooper LM, Dingjan I, Linders PTA, Staal AHJ, Cristescu SM, Verberk WCEP, Van Den Bogaart G. Human monocyte-derived dendritic cells produce millimolar concentrations of ROS in phagosomes per second. Front Immunol. 2019;10(MAY). https://doi.org/10.3389/fimmu.2019.01216

55. Whitcomb EA, Haines BB, Parmelee AP, Pearlman AM, Brodeur PH. Germline Structure and Differential Utilization of of Igha and Ighb VH10 Genes. J Immunol. 1999;162(3):1541-50 (http://www.jimmunol.org/conte nt/162/3/1541).

56. Pham-Ledard A, Prochazkova-Carlotti M, Deveza M, Laforet M-P, BeylotBarry M, Vergier B, Gachard N. Molecular analysis of immunoglobulin variable genes supports a germinal center experienced normal counterpart in primary cutaneous diffuse large B-cell lymphoma, leg-type. J Dermatol Sci. 2017;88(2):238-46. https://doi.org/10.1016/j.jdermsci.2017.07.008.

57. Walsh SH, Rosenquist R. Immunoglobulin Gene Analysis of Mature B-Cell Malignancies: Reconsideration of Cellular Origin and Potential Antigen Involvement in Pathogenesis. Med Oncol. 2005;22(4):327-42. https://doi. org/10.1385/MO:22:4:327.

58. Fuchs T, Hahn M, Ries L, Giesler S, Busch S, Wang C, Neumaier M. Expression of combinatorial immunoglobulins in macrophages in the tumor microenvironment. PLOS ONE. 2018;13(9):e0204108. https://doi.org/10. 1371/journal.pone.0204108.

59. Tu LN, Timms AE, Kibiryeva N, Bittel D, Pastuszko A, Nigam V, Pastuszko P. Transcriptome profiling reveals activation of inflammation and apoptosis in the neonatal striatum after deep hypothermic circulatory arrest. J Thorac Cardiovasc Surg. 2019;158(3):882-890.e4. https://doi.org/10.1016/j. jtcvs.2019.02.091.

60. Morishita H, Yagi T. Protocadherin family: diversity, structure, and function. Curr Opin Cell Biol. 2007. https://doi.org/10.1016/j.ceb.2007.09.006 